Original article

DOI: http://doi.org/10.20914/2310-1202-2018-2-458-463

\title{
Analysis of Sapta Pesona (Seven Enchantments) Implementation in Tourism Village: Study at Pujon Kidul Tourism Village of Malang Regency, Indonesia
}

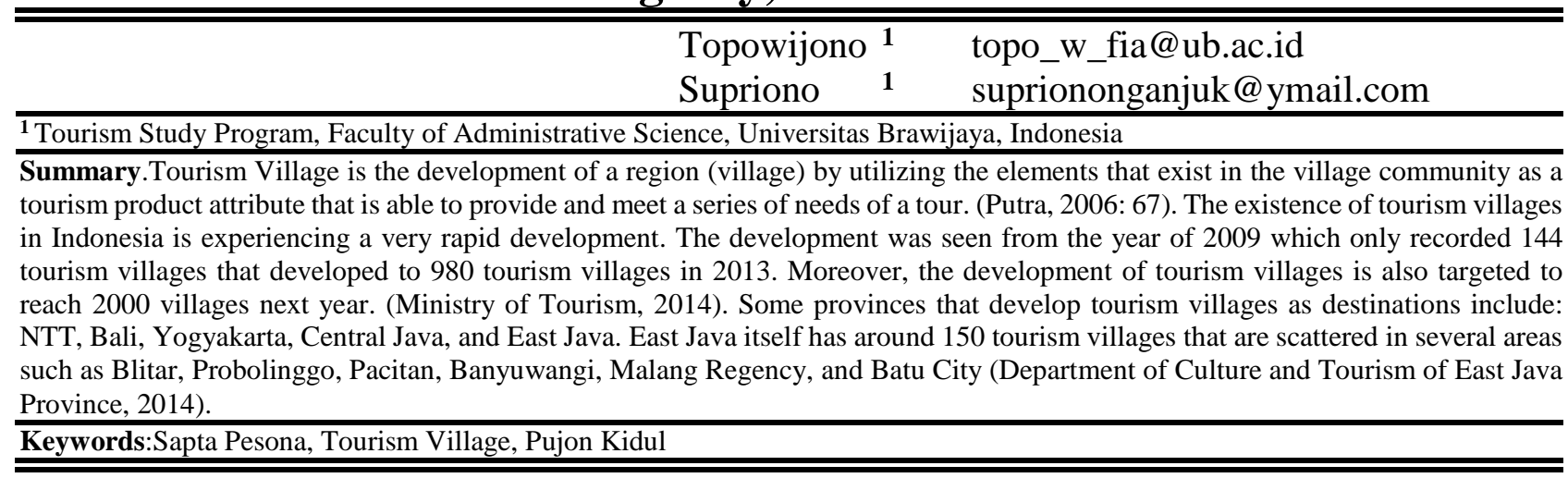

\section{Introduction}

Tourism Village is the development of a region (village) by utilizing the elements that exist in the village community as a tourism product attribute that is able to provide and meet a series of needs of a tour. (Putra, 2006: 67). The existence of tourism villages in Indonesia is experiencing a very rapid development. The development was seen from the year of 2009 which only recorded 144 tourism villages that developed to 980 tourism villages in 2013. Moreover, the development of tourism villages is also targeted to reach 2000 villages next year. (Ministry of Tourism, 2014). Some provinces that develop tourism villages as destinations include: NTT, Bali, Yogyakarta, Central Java, and East Java. East Java itself has around 150 tourism villages that are scattered in several areas such as Blitar, Probolinggo, Pacitan, Banyuwangi, Malang Regency, and Batu City (Department of Culture and Tourism of East Java Province, 2014).

One of the interesting tourism village is Pujon Kidul Tourism Village in Punten Village. This village was formed due to the price of apple stone which in 2007 decreased dramatically, while the majority of the population in the village works as an apple farmer. Some residents who worry about the future of the village finally held a meeting and formed Pujon Kidul Tourism Village. This tourism village offers a variety of tour packages that prioritize the natural atmosphere of the countryside and community participation such Implementation in Tourism Village: Study at Pujon Kidul Tourism Village of Malang Regency, Indonesia// Вестник ВГУИТ.2018. Т 80. № 2. C. 458-470. doi:10.20914/2310-1202-2018-2-458-470 as homestay packages, rafting, agricultural education packages, camp ground packages, farm packages and more.

As a tourism village, the implementation of the concept of Sadar Wisata (tourism awareness) and Sapta Pesona (seven enchantments) becomes an important thing in the basis of its development. Based on the results of observations, it is seen that there are only a few parties who understand the concept, such as the coordinator of the Tourism Village manager. The majority of the community around the village do not understand about the concept. They are only limited to follow the direction of the coordinator. It makes the implementation of Sapta Pesona in Pujon Kidul Tourism Village become less optimal. As in terms of hygiene and superior products that will affect the element of memories to tourists. Therefore, this study tried to describe the implementation of Sapta Pesona in Pujon Kidul Tourism Village of Malang Regency.

\section{Literature review \\ Tourism and Tourism Village}

Tourism is defined as a trip that is made repeatedly or circling from one place to another (Suwena, 2010: 12) and according to Damanik and Weber (2006: 1), it is a very complex phenomenon of human movement, goods and services. It is closely linked to organizations, institutional and individual relationships, service needs, provision of service needs, and so on. On the other hand,

\section{For citation}

Topowijono, Supriono Analysis of Sapta Pesona (Seven Enchantments) Implementation in Tourism Village: Study at Pujon Kidul Tourism Village of Malang Regency, Indonesia. Vestnik VGUIT [Proceedings of VSUET]. 2018. vol. 80 no. 2. pp. 458-470.. doi:10.20914/2310-1202-2018-2-458-470 
Nuryanti (1993: 2-3) defined Tourism Village as a form of integration between attractions, accommodation and supporting facilities presented in a community life structure that integrates with the prevailing rules and traditions. According to the Pariwisata Inti Rakyat (PIR) (in Priasukmana 2001: 38), a tourism village is a rural area that offers a whole atmosphere that reflects the authenticity of the countryside, both from socio-economic, sociocultural life, customs, and everyday life, which possesses typical building architecture and village spatial structure, or economic activity which is unique and interesting, and has the potential for the development of various components of tourism, for example: accommodation attractions, food and beverages, and other tourism needs. Referring to the definition of a tourism village, the establishment of a village to be called a tourism village must meet several requirements. Priasukmana and Muyadin (2001: 38) explained it in several points that can be summarized, as follows:

1. Have good accessibility so as to facilitate tourists to visit the tourism village and the surrounding attractions.

2. There is a good tourist attraction in the form of nature, cultural arts, legends, local food, etc, that can be developed as a tourist attraction.

3. There is support from the community around the tourism village in serving tourists, either by providing accommodation and maintaining the condition of security and order in the village.

Furthermore, Priasukmana and Muyadin (2001: 38-39) outlined the purpose of developing a tourism village, as follows:

1. To support government programs in tourism development by providing alternative tourism object.

2. To explore the potential of villages for community development around the tourism village.

3. To expand the field of employment and field of work for the villagers, so as to improve the welfare and quality of life of villagers. Thus, there will be equitable distribution of economic development in the village.

4. To encourage urban people who are relatively better economically, to be happy to go to the village for recreation (ruralization).

5. To grow a sense of pride for the villagers to remain in their village, thus, reducing urbanization.

6. To accelerate the mixing between non-indigenous people and indigenous people.

7. To strengthen the unity of the nation, so as to overcome disintegration.
These objectives are expected to benefit stakeholders in developing tourism villages. Hadiwijoyo (2012) explained that with the existence of tourism village, then the values of customs and culture that has been going on for tens of years in the village can be preserved and can serve as a tourist attraction that can be enjoyed by tourists. The existence of a tourism village can also generate new potential employment opportunities for the development and empowerment of local villagers so that there is an improvement in living standards and the economy of the community. Another benefit is the creation of a beautiful environment, because basically, tourism village people are required to be more friendly with nature, given that the beauty and coolness of the environment will be one of the attractions for tourists to visit.

\section{Sapta Pesona}

The term Sapta Pesona (Seven Enchantments) was first mentioned in the Seven Wisdom Strategies of Tourism in Pelita V (re: Five-Year Development of Volume Five) which was produced after following World Tourism Market (WTM) as a sign of the beginning of the era of international tourism promotion. The seven basic tourism strategy policies are:

1. Consistency in tourism promotion

2. Addition in accessibility

3. Enhancement of quality of service and tourism products

4. Development of tourist destination areas

5. Promotion of natural attractions, animals, and marine tourism

6. Enhancement of quality of human resources

7. Implementation of a tourism campaign through Sapta Pesona (source: Binus University, 2015)

Sapta Pesona then becomes a stand-alone program based on the Decree of Ministry of Tourism, Post and Telecommunication No.5/UM.209/MPPT-89 concerning Guidelines for the Implementation of Sapta Pesona. This Ministerial Decree defines Sapta Pesona as a condition that must be realized in order to attract tourists to visit an area or region in the country of Indonesia. It is also mentioned that Sapta Pesona consists of seven elements, namely: Safe, Orderly, Clean, Cool, Beautiful, Friendly, and Memorable. The seven elements are heavily campaigned as the principle of Indonesian tourism products along with the launching of the first Visit Indonesia Year (VIY) in 1991. Sapta Pesona consists of: Safe, Orderly, Clean, Cool, Beautiful, Friendly, and Memorable. 
Tourism Awareness Illumination of Department of Tourism, Post and Telecommunications of Directorate General of Tourism (1993: 73-75) defined Sapta Pesona as follows:

\section{Safe}

Safe is a condition or circumstance that provides a calm atmosphere and sense of peace for tourists. Safe also means to be free from fear and worry about the salvation of his soul, body and property (luggage and attachment to his body). It also means free from threats, harassment and violence or crime. Safe, in the sense of including the use of facilities and infrastructure, namely from technical and other disturbances, because the facilities and infrastructure are well maintained.

2. Orderly

Orderly is a condition or circumstance that reflects an orderly atmosphere and discipline in all people's lives. The orderly state or atmosphere in facing the tourists is more directed to: orderly in terms of regulations, orderly in terms of time, orderly in terms of quality of service, orderly in terms of information.

\section{Clean}

Clean is a condition or circumstance that displays a clean and healthy (hygienic) environment. The clean environment should always be reflected in clean and neat environment and tourism facilities. The use of service equipment that is always well maintained, clean, and free from bacteria and pests. Healthy food and beverages, as well as the appearance of clean and physical service personnel. Clean in terms of environment where travelers will find a clean environment from garbage, sewage, dirt.

\section{Cool}

Cool is a condition or state of the environment that provides a fresh, comfortable atmosphere. Such environmental conditions are created by the effort to create a good atmosphere of environment, gardening and greening of the tourist track. Beautify the face of the city with the development of parks in open spaces, greening along the road, neighborhood and offices and shopping centers as well as neighborhoods of residential and tourist attractions. Inside the room, it can be created with the provision of potted plants, and if possible, make an indoor garden.

\section{Beautiful}

Beautiful is a condition or circumstance that reflects a regular, orderly and harmonious arrangement. So it radiates beauty.

6. Friendly

Friendly is the nature and behavior of people who are familiar in the association, respectful and polite in communicating, likes to smile, likes to say hello, likes to give service and to help without expecting any rewards, both given by officers/apparatus of government element and also tourism business which directly serve the tourist.

\section{Memorable}

Through memorable element, tourists can get beautiful and deep memories of the places they have visited. They also get a clean and comfortable accommodation with friendly waitresses, high value of cultural art performances, delicious regional specialties and the availability of interesting and easy-to-take souvenirs.

\section{Research methods}

This research was done by using qualitative descriptive method. Data collection was conducted by in-depth interview to the stakeholders of Pujon Kidul Tourism Village who has been appointed purposively, covering the Village Head, Community, Tourism Village Institution Coordinator, and Tourists visiting Pujon Kidul. Data analysis was done by using Source Triangulation.

\section{Research result}

\section{Implementation of Sapta Pesona in Pujon Kidul Tourism Village}

Sapta Pesona is a conceptualization of Sadar Wisata (tourism awareness) concept related to the support and role of the community as the host (A Guide of Tourism Awareness Group, 2012:11). Through the theory, the implementation of Sapta Pesona requires public awareness of tourism potential in the region. At first, Pujon Kidul Hamlet is just an ordinary village that most of the community works as farmers. The emergence of awareness of tourism originated from outsiders who convince the community that Pujon Kidul has the potential to be a tourism destination. Thus, it encourages the community to create a Tourism Awareness Group as a subject that implements a Sapta Pesona in Pujon Kidul Hamlet.

\section{a. Safe}

Security becomes a very important condition in the tourism industry. As meant by UNWTO (2011) that safety and security is very important in supporting the quality of a tourism destination. In the past two decades, security and safety have become increasingly complex issues and have a profound impact on the sustainability of travel and tourism activities (Kövári and Zimányi, 2011:59). As a tourist destination, Pujon Kidul Tourism Village performs some form of action related to security. Such forms of action have been in 
accordance with theories contained in the Guideline of Tourism Awareness Group (2012) on the forms of action that need to be manifested to create a sense of security, which consist of: having an attitude of not interfering with the convenience of tourists in their visits, helping and protecting the tourists, maintaining environmental security, and minimizing the risk of accidents in the use of public facilities.

\section{b. Clean}

Cleanliness of the environment around the tourist area is another important matter to note. According to Khalik (2014: 29), the environment around the tourism area should be maintained by not doing any littering and maintaining cleanliness in public facilities. If viewed from the point of view of environmental health, littering can cause disease and can damage the existing ecosystems. Its application is reflected through several forms of action that lead to clean conditions that are free of waste, dirt, pest and diseases.

\section{1) Not doing a littering}

Equipping tourists with a trash bag on fruit picking package is one of the actions that the manager has done so that tourists do not throw garbage carelessly. But it is not matched by the availability of garbage cans at other tourist package locations, such as in outbound packages, industrial packages, and others. The availability of garbage cans in Pujon Kidul Village is less than the number of groups that usually come and stay in the village, that is over 50 people.

2) Maintaining environmental cleanliness of tourist objects, attractions and supporting facilities.

The people of Pujon Kidul Tourism Village really keep their environment clean. Environmental hygiene is generated from the activities of mothers who diligently clean the house and surrounding area in the morning and evening, coupled with the voluntary work that is routinely conducted in Pujon Kidul Village, as the suggestion of head of Community Association ( $R W)$. Environmental hygiene is also applied in the package of tour packages provided. As with homestays, rabbit farms, dairy sites, fruit packets, and chips production sites. In the picking fruit tour package, the manager provides crackle (trash bag) that can be used to accommodate the trash.

3) Clean and neat appearance of the clerk

One of the form of appreciation towards tourists who come visiting the village is by having a good appearance in front of the tourists. Based on observation, managers can dress neatly in accordance with what is handled by them, and it does not have to be a uniform. In the meantime, uniforms are only owned by outbound officers. Therefore, managers use pins as identity that distinguishes them with the tourists during their duty.

\section{d. Cool}

Maintaining coolness is tantamount to maintaining a sustainable tourism destination. According to UNWTO (2005), the development of tourism destination that does not care for environmental sustainability will not only damage the society and the environment, but it will also damage the tourism itself. Therefore, keeping the coolness of a tourism destination can be done by several things, namely: by maintaining cool conditions in the public area through planting; and maintaining the surrounding greening activities in accordance with the form of action listed in the Guideline of Tourism Awareness (2012).

1) Carrying out reforestation by planting trees.

Greening that is done in Pujon Kidul is conducted by planting crops that are in the form of productive plants, such as vegetables, flowers, and fruits. It is basically aimed not only to keep the coolness, but also to utilize the surrounding land for profit.

2) Maintaining cool conditions in public areas/public facilities like hotels, inns, restaurants and other infrastructure facilities and tourism components/facilities.

The biggest source of pollution in Pujon Kidul Tourism Village comes from motor vehicles used in rice fields or gardens. The vehicle is an ordinary motorcycle that is then modified to be used for muddy and uphill roads to bring crops and grasses to farm animals. This modified motorcycle produces a loud sound and exhaust gases.

\section{e. Beautiful}

Making tourists feel at home and want to continue to return to the tourist destination is a goal that always want to be achieved by every tourist destination. One of the way to achieve the goal is by maintaining the beauty and sustainability of nature which is an asset of Indonesian tourism (Suwena, 2010: 104). In essence, man always requires the beauty of the harmonization of biodiversity for the peace of soul, pleasure and peace (Hakim, 2014: 229). Therefore, it is necessary to realize a condition of environments that reflect beautiful and interesting circumstances by doing things like keeping objects and attractions in an aesthetic order, preserving the character of localization, and preserving the beauty of vegetation as written in the Guideline of Tourism Awareness Group (2012). Almost all houses of residents are equipped with plants that can add value to the beauty of the environment, whether it is an ornamental plant or productive plant such as vegetables and fruits. The results of this observation is also felt by tourists who visit the village. 


\section{f. Friendly}

Society takes an important role in realizing the friendly conditions to tourists who come to visit the Tourism Village. Suwena (2010) stated that the involvement or support of the community in tourism activities greatly affects the tourist visits. Good and friendly attitude given to the tourists will make the tourists feel at home in a tourist destination. The importance of community support is also a requirement for the formation of a Tourism Village where the community and village officials are expected to receive and give high support for tourist (Priasukmana and Muyadin, 2001: 38). As a Tourism Village which is closely related to community involvement, Pujon Kidul Tourism Village has implemented several things to reflect the friendly element that are in accordance with the Guideline of Tourism Awareness Group (2012), as follows:

1) Being a good host and willing to always be ready to help tourists.

One of the form of community's tourism awareness based on Guideline of Tourism Awareness Group (2012:9) is to realize the role and responsibility as a host that is good for guests or tourists. In the implementation, it can be said that managers have been a good host and willing to help the tourists. This is evident from the form of assistance and attitude of the community that is very friendly to tourists. The friendly attitude of the community is the original character of the local community. This attitude is then supported by the training of trainers as well as tourists about the friendliness of the community.

2) Giving information politely.

The next form of action of the friendly element that is applied is to provide information politely. The absence of written rules to tourists makes managers and the public giving information to tourist orally. This behavior has been applied well in Pujon Kidul Tourism Village, both by the manager and the community of Pujon Kidul Village itself, even though they are still experiencing difficulties when having communication with foreign tourists.

\section{g. Memorable}

Memories are a form of memorable experience in a tourist destination that can create a good impression for tourists. Memories become a matter of concern because it will determine the positive impression that will be conveyed to others and a return visit from tourists. Yoeti stated (in Suwena 2010: 85) that a tourist destination should have at least three conditions: something to see, something to do, and something to buy (something which can be purchased). That is, a tourism destination should be able to provide good memories in the form of experience through something to see and something to do or in the form of souvenirs through something to buy. The forms of action that can be realized as listed in the Guideline of Tourism Awareness Group, as follows:

1) Exploring and elevating the uniqueness of local culture.

Culture in Pujon Kidul Tourism Village can be said to range from the art of music, dance, to customs. There are kentrung music, crazy bamboo, waltz dance, village cleaning ceremony, and others. Most of the cultural arts possessed have entered into the tour packages offered, except for a traditional ceremony that only happens once a year and is sacred. This is intended for tourists to know the art of culture in Pujon Kidul Tourism Village.

2) Serving local food and drink that is clean, healthy and attractive.

Pujon Kidul Tourism Village has a typical food menu, that is Empok rice. Empok rice is corn rice which is equipped with melted, spicy vegetable, coconut milk and salted fish. However, this food is rarely served because in Pujon Kidul Tourism Village, this food menu will be tailored to the desires of tourists. There are tourists who prefer to cook their own food to be used as bounding time, there are tourists who have ordered catering from outside the village, there are also tourists who already have their own menu according to their own taste. This makes the typical local food and drink can not be shown optimally because it adjusts the wants and needs of tourists. The results of this observation are in accordance with the results of the perception questionnaire of tourists who earn on average enough statement on the impression gained from the typical food served by the tourism village.

3) Providing interesting, unique, and portable souvenirs.

Memorable element is closely related to souvenirs to take home by the tourists that can be stored alone and given to others. In the meantime, a souvenir that can be brought home from Pujon Kidul Tourism Village is a variety of chips. There are several kinds of processed chips that are made, namely: carang mas, ginger chips, apple chips, spinach chips, oyster mushroom chips, potato chips, jackfruit chips, rambutan chips, salak chips, tempe chips, and purple sweet potato chips. Pujon Kidul Tourism Village does not have typical souvenirs because of the limitations on existing human resources and skills. Therefore, until today, souvenirs offered to tourists are only chips. 


\section{Conclusion}

Based on the formulation of the problem, the results of research, and discussion, it can be concluded that almost all of the seven points of the implementation of Sapta Pesona in Pujon Kidul Tourism Village can be done well. This is evidenced by the absence of complaints from tourists who have visited the village, and if there are any complaints from them, then the Tourism Village directly improve themselves.

\section{Suggestions}

The researchers suggest to Ministry of Tourism to always update the guidelines of tourism awareness which includes the explanation about the points of Sapta Pesona, considering the increasing number of tourist destinations involves the role of local communities. For the next researchers, they are sugested to conduct a research about the effectiveness of applying Sapta Pesona in other Tourism Village.

\section{REFERENCES}

1 Muljadi A.J. Kepariwisataan dan Perjalanan. Jakarta: PT. Raja Grafindo, 2010

2 Bahan Baku Penyuluhan Sadar Wisata Departemen Pariwisata. Departemen Pariwisata, Pos dan Telekomunikasi. Direktorat Jenderal Pariwisata. 1993

3 Damanik, Janianton dan Weber, Helmut. Perencanaan Ekowisata Dari Teorike Aplikasi. Yogyakarta: PUSPAR UGM dan Andi, 2006

4 Gunawan Imam Metode Penelitian Kualitatif: Teori dan Praktik. Jakarta: Bumi Aksara, 2014

5 Hadiwijoyo, Suryo Sakti Perencanaan Pariwisata Perdesaan Berbasis Masyarakat (Sebuah Pendekatan Konsep). Yogyakarta: Graha Ilmu, 2012.

6 Hakim, Luchman.2014. Enobotani dan Manajemen Kebun - Pekarangan Rumah: Ketahanan Pangan, Kesehatan, dan Agrowisata. Malang: Selaras

7 Pedoman Kelompok Sadar Wisata Direktorat Jenderal Pengembangan Destinasi Pariwisata Kementerian Pariwisata dan Ekonomi Kreatif. 2012. Jakarta: Persada

8 Sunaryo, Bambang. 2013. Kebijakan Pembangunan Destinasi Pariwisata: Konsep dan Aplikasinya di Indonesia. Yogyakarta: Gava Media

9 Suwena, I Ketut dan I Gst Ngr Widyatmaja. Pengetahuan Dasar Ilmu Pariwisata. Denpasar: Udayana University Press 10 Unep dan Unwto. Making Tourism More Sustainable: A Guide for Policy Makers, 2005

11 Unwto Tourist Safety and Security: Practical Measures for Destinations. Madrid: World Tourism Organization, 2011

12 Yoeti Oka A. Ilmu Pariwisata: Sejarah. Perkembangan dan Prospeknya. Jakarta: Pertja, 2001

13 Priasukmana, Soetarso dan R. Mohamad Mulyadin. Pembangunan Desa Wisata: Pelaksanaan Undang-Undang Otonomi daerah. Jurnal Info SosialEkonomi. 2001. vol. 2. no. 1. pp. 37-44

14 Nuryanti, Wiendu Concept, Perspective and Challenges, makalah bagian dari Laporan Konferensi Internasional mengenai Pariwisata Budaya. Yogyakarta:Gadjah Mada University Press, 1993.

15 Khalik, Wahyu Kajian Kenyamanan dan Keamanan Wisatawan di Kawasan Pariwisata Kuta Lombok. JUMPA. 2014. vol. 1. no.1. pp. 23-42

16 Kövári, István dan Zimányi, Krisztina Safety and Security in the Age of Global Tourism (The changing role and conception of Safety and Security in Tourism). Budapest: Agroinform Publishing House, 2011.

17 Stanford, Davina Responsible Tourism, Responsible Tourist: What Makes a Responsible Tourist in New Zealand. Victoria University of Wellington, 2016

18 Keputusan Menteri Pariwisata, Pos dan Telekomunikasi Nomor.5/UM.209/MPPT-89 tentang Pedoman Penyelenggaraan Sapta Pesona

19 Peraturan Menteri Kebudayaan dan Pariwisata Nomor: PM.04/UM.001/MKP/2008 tentang Sadar Wisata

20 Republik Indonesia Undang-Undang Nomor 10 Tahun 2009 Tentang Kepariwisataan. Jakarta, 2016

\section{INFORMATION ABOUT AUTHORS}

Topowijono Tourism Study Program, Faculty of Administrative Science, Universitas Brawijaya, Indonesia topo_w_fia@ub.ac.id

SuprionoTourism Study Program, Faculty of Administrative Science, Universitas Brawijaya, Indonesia supriononganjuk@ymail.com

\section{CONTRIBUTION}

Topowijonowrote the manuscript, correct it before filing in editing and is responsible for plagiarism Suprionoreview of the literature on an investigated problem, conducted an experiment, performed computations

CONFLICT OF INTEREST

The authors declare no conflict of interest.

RECEIVED 3.15.2018

ACCEPTED 5.11.2018 